\title{
INFLUENCE OF AUDITOR INDEPENDENCE AND GOOD CORPORATE GOVERNANCE TOWARD ACCOUNTING CONSERVATISM IN
}

\section{INDONESIA}

\section{(Empirical Study On Manufacturing Companies Listed In Indonesia Stock}

\author{
Exchange 2010-2014) \\ Dovi Spetiari ${ }^{1}$, Wirdani Atika Sari ${ }^{2)}$ \\ Managerial Accounting Department, Politeknik Negeri Batam \\ Jl. Ahmad Yani, Batam Centre, Batam 29461, Indonesia \\ 1) E-mail: dovi@ polibatam.ac.id \\ ${ }^{2)}$ E-mail: wirdhany@gmail.com
}

\begin{abstract}
Accounting conservatism is the precautionary principle to the profit recognition and one of the corporate governance to reduce the ability of the manager in manipulate and exaggerating the financial statements. Corporate governance is a internal control system which has its business objectives through securing company's assets. This research is aiming to see the correlation among auditor independence and good corporate governance in accounting conservatism. Characteristics of good corporate governance in this are managerial ownership, profitability, company size and leverage. This research uses two measurements of conservatism non operating accrual and market to book ratio. This research as carried out at manufacture company in the Indonesia Stock Exchange in 2010-2014. Sample selection do by purposive sampling method and obtained 49 companies in criteria accordingly. This research used data analysis and multiple liniear regression program eviews 9. The result showed that the effect of auditor independence is not significant in accounting conservatism in indonesia. Good corporate governance influential only the size of the company and ownership. The measurement of non operating accrual and market to book ratio show different results. Further research is expected to use another proxy for other variables to measure accounting conservatism.
\end{abstract}

Keywords: Conservatism accounting, good corporate governance, non operating accrual and market to book ratio.

\section{Introduction}

The financial statements of a company's performance reflects the company's management in managing the resources entrusted. Information provided is used by internal and external parties. In Indonesia, the financial statements are prepared based on the Statement of Financial Accounting Standards (PSAK) issued by the IAI. Accepted Accounting Principles provide flexibility for management to determine the accounting methods used. Efforts to help managers conduct financial reporting recognition it gives birth to the concept of accounting conservatism

Accounting conservatism became a hot issue to be discussed because this principle there is a lot of criticism that appears either support or reject the criticism that the application of the principle of conservatism. This principle is still considered a controversial principle [11]. [14] explained in the last 
decade there was an increase in the use of a conservative financial statements for companies in the United States. This proves even though many parties criticize but accounting conservatism is still seen as a useful method for financial statement users.

There are several factors that can affect whether the company will apply the method is conservative. The size of the ownership management can give effect to conservatism within the company. This is certainly encouraging management to implement a more conservative accounting within the company. Another factor affecting the conservatism is leverage and firm size. [17] states that the company's leverage and size can affect the level of accounting conservatism.

Companies that have a higher debt, the creditor has the right to know and supervise the company's accounting so that creditors tend to ask the manager held a conservative accounting [17]. Large-sized enterprise will certainly get close supervision of the government and the public so that the company will hold conservative accounting to report lower profits [17]. Another factor affecting conservatism is profitability. The larger the company's profitability and debt levels, the level of accrual accounting conservatism with the greater size [24].

A previous study by [2] examine whether the auditor independence shown by non-audit fees affect the level of accounting conservatism in Australia. Total sample of 1874 public companies in Australia, this study shows that the level of economic ties between the auditor and the client does not significantly affect the level of accounting conservatism in Australia. This means that the combination of market mechanisms and regulation in Australia intrinsic adequately protect the independence of auditors.

The study, using accounting conservatism as the dependent variable has several times conducted among others by Siska (2012), Wardhani (2008), Almilia (2003), Bahaudin (2011), Dewi (2014), Yona (2013). Almilia (2003) states that the lower the size of the company, the company will present a conservative financial statements. The higher the debt to total asset ratio of the financial statements of companies tend to be conservative. Research [6] the independence of the commissioner as measured using the accrual value indicates the absence of a positive relationship and the results are not in line with the research [1].

[24] showed that the presence of an audit committee positive effect on the level of conservatism using the accrual size. This study can not prove the influence of the independence commissioner and managerial ownership on the level of the company's accounting conservatism. The results of the study [23] showed that the independent board, managerial ownership, institutional ownership and audit quality significantly influence coefficient ERC (Earning Response coeficient).

Research [27] states that managerial ownership does not affect the management to adopt accounting conservatism while [11] showed that managerial ownership has a significant positive effect which means that managers tend to prefer conservative accounting if the shares held high management.

Based on the description above background. This research is the development of research [2] in Australia and the results are inconsistent by some previous studies, this study intends to examine the effect of the mechanism of auditor independence and good corporate governance to the level of accounting conservatism in Indonesia by adding some variables and using the data companies listed on the Stock Exchange Corporate Governance in the implementation mechanism of the level of accounting conservatism.

\subsection{Formulation Problems}

This study will examine how the influence of auditor independence and the mechanisms of good corporate governance which is proxied by managerial ownership, profitability, leverage and the size of the company to the level of accounting conservatism on manufacturing companies listed in Indonesia Stock Exchange 2010-2014.

\subsection{Research purposes}

Interest researcher conducted this study was to examine the effect of the mechanism of auditor independence and good corporate governance to 
accounting conservatism as measured by non-operating accrual and market to book ratio.

\subsection{Benefit of research}

The benefits of such research is Adding an understanding of one of the accounting principles that accounting conservatism that is influenced by several factors, provide a reference for future research on accounting conservatism, this research can be a reference in applying the precautionary principle on the financial statements of companies as well as providing knowledge in decision decision.

\section{Theoritical and Literatur Review}

\subsection{Theoritical basic}

\subsubsection{Accounting Conservatism}

PSAK as the accounting standards in Indonesia to trigger the application of conservative accounting. Application of accounting conservatism in PSAK reflected in the method of recording in the same conditions. This raises a number of different figures in the financial statements resulting profits tend to be conservative. The choice of method of recording has been arranged in FRS are:

a. PSAK No. 14 on inventory stated that the company can record the cost of inventory using the average, LIFO and FIFO (First In First Out).

b. PSAK No. 16 on fixed assets. Estimated useful life of an asset is based on management considerations. The estimated useful lives are periodically re-examined. When management found that the useful life of an asset is different from previous estimates, the management must make adjustments to depreciation expense at the moment and in the future. This standard allows companies to change the useful lives of the assets used and cause more conservative earnings.

c. PSAK No. 19 on intangible assets related to the amortization method. Some of the amortization method for allocating the amount of depreciation of an asset on a systematic basis throughout its useful life. Regarding research and development in PSAK No. 19 defines research as original and planned research performed in the hope of getting an update on the technical knowledge and understanding of the new science. The allocation of research and development costs are determined by looking at the relationship between costs and the expected economic benefits of the company. The Company shall not recognize an intangible asset arising from research (or from the research phase to an internal project).

The presence of accounting conservatism in the financial statements of a company that is desirable for investors because it provides confidence to investors and the public.

[25] stated that the financial statements with the principle of conservatism consists of several economic reasons. In fact, conservatism generally consists of:

a. Conservatism role in efficient technology employees in corporate governance (eg corporate compensation) and contracting company with external parties (eg debt contract).

b. The increase in litigation boarding.

c. Regulators 'asymmetric function loss'.

d. The relationship between the income statement and income tax.

Conceptually, the application of this conservatism produce problems because do not report the actual values. In fact, this principle is still used by accountants.

\subsubsection{Prudent reaction in accounting conservatism}

Glossary definition of conservatism No. 2 FASB (Financial Accounting Board Statement) defines conservatism as a reaction prudence (Prudent reaction) in the face of uncertainty and risk inherent in the corporate environment. The concept of prudence (Prudent reaction) company must maintain in order not to overestimate the amount of revenue recorded.

\subsubsection{Timeliness in accounting conservatism}

[5] states that the asymmetric timeliness in the recognition of news is expected to materialize as well as persistent asymmetric profit. Financial reports are often considered bad news capitalized as a loss, bad earnings news is more timely but less persistent. Since 
accountants anticipate future losses but not gains in the future, conservatism earnings results more timely and simultaneously more sensitive to the public provided bad news than good news.

\subsubsection{Good Corporate Governance}

Some of the concepts of good corporate governance has been put forward by experts. According to [12] in his book The Power of Good Corporate Governance states that good corporate governance is the company's internal control system which has the primary objective to manage significant risks in order to meet its business objectives by securing company's assets and increase the value of shareholders' investment in the long term. [28] states that corporate governance with regard to how to convince the owners of capital in obtaining the return on investment to have been planted. Told as a means to ensure the manager provides the best interests of shareholders.

OECD see Corporate governance as a system whereby a business entity directed and supervised. In the principles of Good Corporate Governance drawn Organization for economic cooperation and development (OECD) includes justice (fairness), transparency (Transparency), accountability (accountability) and responsibility (responsibility).

Political model stating that the allocation of power within the company, or the allocation of profits among the owners, managers and other stakeholders is determined by political considerations. In this case the government can play an important role in determining the allocation. The allocation of power in the theory of corporate governance should also be viewed from the perspective of culture, so it can be said there is no single model of corporate governance that can be used simultaneously for multiple countries, even by several companies in a single country. Stewardship theory assumes that the personal interests between managers and shareholders can be harmonized through the achievement of organizational goals. Stewardship theory of corporate governance, such as the belief that the company's management conducted by the management by delegation of responsibility and authority by the company.

\subsection{Literatur Review}

[23] examined the conservatism of accounting, corporate governance and the quality of earnings with sample manufacturing company in Indonesia Stock Exchange in 2008-2010. The results showed that the independent board, managerial ownership, institutional ownership and audit quality significantly influence coefficient ERC (Earning Response coeficient).

[27] examined the effect of accounting conservatism on equity valuation with good corporate governance as a moderating variable with empirical studies on companies listed on the Stock Exchange. Research results show that conservatism positive significant effect on equity valuation, managerial ownership does not significantly influence the relationship of accounting conservatism, the number of commissioners to strengthen ties with the accounting conservatism equity valuation on companies listed on the Stock Exchange.

Research [2] states that the auditor's independence is very important for the Australian financial system. The results showed that the level of economic ties between the auditor and the client with the path coefficients is positive not significantly affect the level of accounting conservatism. This is because the regulation of Australia is strong in corporate governance and the independence of the auditor in Australia.

[11] examined the effect of managerial ownership structure, leverage, and financial distress to accounting conservatism. Research conducted at manufacturing companies in BEI periods of 2009-2011 shows that the effect of managerial ownership structure and significantly positive leverage on accounting conservatism while the financial distress had significant influence negatively on accounting conservatism.

[18] examined the influence of corporate governance on accounting conservatism manufacturing company in Indonesia Stock Exchange. The analysis showed that the corporate governance 
affect either conservatism accounting calculated using the accrual method or methods of market to book ratio. This study found that the influence of corporate governance on accounting conservatism higher when calculated by the method of the market.

\subsection{Hypotesis Development}

\subsubsection{Managerial Ownership to Accounting Conservatism}

Managerial ownership can give effect to the company due to the partial ownership of shares by management, directors, commissioners directly involved in company decision-making will lead to financial interests so that management will implement more conservative accounting [19]. Great ownership rate will reduce net profit expected the manager to return on capital that will increase the level of conservatism [26]. Companies with a low stock ownership report will issue more conservative earnings. Conservatism in the financial statements is one mechanism to solve problems when the agency raised the separation between ownership and control [16].

Research [24] found that the negative influence of managerial ownership with accounting conservatism as measured by the ratio of book-to-market. The results of this study contradict the research conducted by [11] which states that managerial ownership has positive influence on accounting conservatism. [18] concluded that ownership by affiliated commissioners and board of directors in the company to the level of conservatism and the market value shows a positive association. Based on these descriptions can be formulated hypotheses as follows:

H1a: managerial ownership positively affects accounting conservatism as measured by market to book ratio.

H1b: managerial ownership positively affects accounting conservatism as measured by non-operating accrual.

\subsubsection{Leverage to accounting conservatism}

Leverage is defined as assets, fixed assets and sources of funds used where for the use of fixed assets and the loan company must pay fixed and interest expense. The higher the leverage, the risk faced by investors will be higher and investors will ask for greater profits. Leverage is said to be beneficial if the company generated profits in excess of the amount of capital employed and fixed costs (interest on bonds and preferred dividends are fixed) [17].

Research [17] states that if a company has a large debt, the creditors have the right to know and supervise the operations of the company. From the results of that study concluded that the creditors have the right to supervise the operations of the company. [1] showed that the higher the leverage, the company will report earnings more conservative. Based on these descriptions formulated the following hypotheses:

H2a: Leverage the company positive effect on conservatism Accounting as measured by market to book ratio.

$\mathrm{H} 2 \mathrm{~b}$ : Leverage the company positive effect on conservatism Accounting as measured by non-operating accrual.

\subsubsection{Profitability to accounting conservatism}

Profitability used a company has an important benefit in the management control system, in the preparation of the target, budget and evaluation of the results of the implementation of the company's operations by the intern. The company's ability to generate earnings will be the basis for dividend distribution companies so that the Company can use the system in order to profit accounting conservatism look flat. [1] states that the lower profitability of the company the higher the cost accounting conservatism. [24] showed that the higher profitability of the company and the greater the return of its shares, the higher the level of conservatism which is measured by the size of the market. Based on these descriptions formulated the following hypotheses:

H3a:Profitability positive effect on accounting conservatism as measured by market to book ratio.

H3b:Profitability positive effect on accounting conservatism as measured by non-operating 


\subsubsection{Size to Accounting Conservatism}

Large size companies typically generate greater profits. This prompted the government to oversee the company, for example by raising tax rates on the company. Not only the government, the community also helped oversee the company's example by seeking increased public services to the company. To avoid this, of course, the company tried to report the income as low as possible by holding a conservative accounting system. Research [17] size companies positive effect on the level of accounting conservatism. [15] states that the bigger the company expected more management in monitoring the performance of the company so that the company's performance to be more effective and efficient. Research [21] stated that the bigger the company, the higher conservatism. Based on these descriptions formulated the following hypotheses:

H4a: Size of the company positively affects accounting conservatism as measured by market to book ratio.

H4b: Size of the company positively affects accounting conservatism as measured by non-operating accrual.

\subsubsection{Auditor independence to accounting conservatism}

[8] states that if an auditor is paid at a price which exceeds the cost of the audit, it is considered less independent auditor. The independence of public accountants may be affected if a public accountant has an interest in a business relationship with the client being audited. Board of Professional Standards of Certified Public Accountants (SPAP) IAI through SPAP (2001: 220.10) states that: "this standard requires the auditor be independent, meaning not easily influenced, because he was carrying out work in the public interest (differentiated in ways he practiced as internal auditors).

The relationship between auditor, auditing, and accounting conservatism has been demonstrated in previous studies. For example [6] found that the big four auditors of corporate clients are more conservative than the non-big-four client companies. This is because the auditor's big four accounting firm level face a higher risk of reputation and litigation because it has more stringent requirements for the accounting treatment of clients.

Research [2] states that the auditor's independence is very important for the Australian financial system. The results showed that the level of economic ties between the auditor and the client does not significantly affect the level of accounting conservatism. This is because the regulation of Australia is strong in corporate governance and the independence of the auditor in Australia. Based on these descriptions formulated the following hypotheses:

H5a: The auditor's independence positive effect on accounting conservatism as measured by market to book ratio.

H5b: The auditor's independence positive effect on accounting conservatism as measured by non-operating accrual..

\section{Result And Discussion}

\subsection{Descriptive analyze}

This study uses two independent variables, auditor independence and good corporate governance which is proxied by the variable profitability, managerial ownership, firm size and leverage. The final results of the election of the sample obtained 49 manufacturing companies that have complete data and the re-pooling to 245 observations. The descriptive statistics for each of these variables can be seen in Table 1.

TABLE 1

\begin{tabular}{cccc}
\hline & Mean & Maximum & Minimum \\
\hline CONAC* & $1.70 \mathrm{E}+11$ & 2624090547563 & $-4.60 \mathrm{E}+11$ \\
CONAC** & 6.978196 & 292.5961 & $-2.70 \mathrm{E}+00$ \\
FIRM & 21.45410 & 29.37009 & 7.605890 \\
INDEP & 0.714286 & 1.000000 & 0.000000 \\
LEV & 7.438057 & 1688.143 & 0.002500 \\
PROF & 0.054736 & 1.140000 & $-2.86 \mathrm{E}+00$ \\
OWN & 0.060396 & 0.958000 & 0.000000 \\
\hline
\end{tabular}

Based on the test results of descriptive statistics

in Table 1 the dependent variable CONACC as a proxy for conservatism which is calculated using a non-operating acrual show positive average which indicates that earnings are not classified in conservative while variable CONACC which is calculated using the size of the market to book ratio has 
averaged 6,978196 this ratio indicates the application of conservative accounting for the company recognizes the company's book value is less than the market value of the company. Average of $6.03 \%$ of managerial ownership is less than $10 \%$. It shows the ownership of shares owned by the management in the company is relatively small. 0.15 standard deviation greater than the average of $0: 06$, it means that the spread of managerial ownership data is uneven because of differences in the data each other is very high.

\subsection{Data Analyze}

The data processing and statistical tests showed that the only managerial ownership and firm size are significant to the measurement of market value while in the non-operating accrual measurement only significant variable firm size. Summary results of hypothesis testing in this study can be seen in Table 2 .

TABEL 2

\begin{tabular}{|l|c|c|c|c|}
\hline $\begin{array}{c}\text { Variab } \\
\text { le }\end{array}$ & $\begin{array}{c}\text { Coefficie } \\
\text { nt MB }\end{array}$ & Prob MB & $\begin{array}{c}\text { Coefficient } \\
\text { NOA }\end{array}$ & $\begin{array}{c}\text { Prob } \\
\text { NOA }\end{array}$ \\
\hline C & 13.93012 & 0.0472 & $-9.49 \mathrm{E}+10$ & 0.4506 \\
\hline PROF & 0.233535 & 0.9707 & $-4.09 \mathrm{E}+10$ & 0.4373 \\
\hline LEV & -0.006059 & 0.7295 & 68228699 & 0.5686 \\
\hline FIRM & -0.499050 & $* * 0.0858$ & $1.45 \mathrm{E}+10$ & $* * 0.0037$ \\
\hline OWN & -19.91180 & $* 0.1163$ & $-6.68 \mathrm{E}+10$ & 0.7817 \\
\hline INDEP & 6.985479 & $* 0.1041$ & $-5.63 \mathrm{E}+10$ & 0.5061 \\
\hline R-squared MB & \multicolumn{3}{|c|}{0.027754} \\
\hline R-squared NOA & \multicolumn{3}{|c|}{ Random effect } \\
\hline N & \multicolumn{3}{|c|}{ ownersip to } \\
\hline $\begin{array}{l}\text { Hasil uji Langrange } \\
\text { Multiplier }\end{array}$ \\
3.2.1 Influence of managerial ow \\
acoounting conservatism
\end{tabular}

Results of testing the hypothesis in this study indicate that managerial ownership significant negative effect on the level of $10 \%$ to accounting conservatism as measured by market value as well as non-operating accrual so H1a and H1b are not supported. Nonsignificant results is made possible by descriptive statistics, the average number of shares owned by management at a manufacturing company in Indonesia is relatively small at $6.04 \%$ smaller than $10 \%$ so that managerial ownership is relatively small allowing conflicts of interest between shareholders and the manager where the interests of managers can not be aligned with shareholder interests so that managers are yet to have the company. In addition, non-operating accrual measurements on a sample of companies that obtained indicate more companies are optimistic than the conservative company.

The results of this study support previous research by [24] with accrual measurement so that the measurement [14] which consists of non-operating accrual and accrual can not prove the effect of managerial ownership on accounting conservatism. Research conducted by [3] with model measurements accrual by Zhang (2007) also showed a negative effect but not significant.

\subsubsection{Influence leverage to accounting conservatism}

Results of testing the hypothesis in this study indicate that $\mathrm{H} 2 \mathrm{a} \mathrm{H} 2 \mathrm{~b}$ negative and positive effect but not statistically significant so H2a and H2b unsupported. The results of this study are not supported because the average ratio of debt / total assets amounted to 7.43 means that the company's assets are financed by debt is so large that the company's managers will choose accounting procedures that increase in reported earnings is not conservative. Leverage the company no significant effect on the increase and decrease in the ratio reflects the market value of the application of the principle of accounting conservatism. Debts owed by companies both large and small amounts to not affect the management policy to apply the principles of conservative, because lenders believe the security of loans granted to the company. Companies listed on the Stock Exchange also obtain funds from investors who will invest to the company concerned that the magnitude of the ratio of total debt to total assets has no effect on the application of conservative accounting. The measurement method used is also not able to prove the effect of leverage on konservatsime accounting.

These results are not in line with the research [17], [9]. [17] shows that leverage positive effect on accounting conservatism with VIKV measurement while [9] shows that leverage negatively affect the measurement accrual accounting conservatism. 


\subsubsection{Influence profitability to accounting conservatism}

Results of testing the hypothesis in this study indicate that $\mathrm{H} 3 \mathrm{a}$ positive effect and $\mathrm{H} 3 \mathrm{~b}$ negative effect, but not statistically significant so $\mathrm{H} 3 \mathrm{a}$ and $\mathrm{H} 3 \mathrm{~b}$ not supported means that profitability does not affect the accounting conservatism. The results of this study are not supported because the average profit generated from that used relatively little capital in the amount of $5.47 \%$ with the lowest profit of -2.86 so companies tend to reduce the use of accounting principles that did not experience fluctuating earnings or even look lower. This result indicates that the net profit resulting from the use of the company's total assets had no significant effect on the market-to-book ratios and non-operating accrual reflects the application of the principle of accounting conservatism. Nonsignificant results show that the net income derived from the use of assets does not affect the management policy for applying conservative accounting because the average profit generated in 2010-2014 manufacturing companies tend to be low so that the management does not need to apply the principle of conservatives who make profits fluctuate or unstable. Other factors account the different periods of observation which interprets economic conditions between the study with previous research

The results of this study are not consistent with research conducted by [24]. Results [24] showed similar results are significantly positive, as measured by market value. The results of this study are not consistent with previous studies because of differences in interpreting the study period differences in economic conditions of the study.

\subsubsection{Influence Size To Accounting Conservatism}

Based on the results of statistical tests, $\mathrm{H} 4 \mathrm{a}$ showed that the size of the company negative significant effect on accounting conservatism as measured by market value so H4a unsupported size of the company means that reflected in the total assets of the company described the size of the company. Size companies negatively affect the market value accounting conservatism because the highest value of the firm-size 7.61 to 29.37 while the lowest value so that the small size of the company that encourages managers to present the report tends to be conservative to avoid the high political cost. Based on the political models of companies that have greater assets tend to be more sensitive to the political cost. Cost politics itself arises from a conflict between the manager and the government for which the company are considered partially responsible for the interests of the community. One of them is the obligation to pay taxes. Therefore, in order to avoid tax evasion is high then the management will tend to report lower earnings resulting in an earnings reporting conservative in a great company.

$\mathrm{H} 4 \mathrm{~b}$ indicates that company size significantly and positively related accounting conservatism as measured by non-operating accrual so H4b supported means that the size of the company, the higher accounting conservatism. Conservatism as measured by non perating accrual net income reflects the company so that if the size of large companies, the managers are trying to apply the principle of a more conservative so that profits appear to be low. It aims to avoid large political costs of external parties such as government. The difference between the market value of the research results and the non-operating accrual shows that the effect size of the company accounting conservatism depends on the measurement used.

The results are consistent with research [24],

[9], [10] and contrary to research [3]. Research [9] and [10] showed that the size of the company's positive effect on conservatism accrual and non-accrual operating companies.

\subsubsection{Influence Auditor Independence To Accounting Conservatism}

Results of testing the hypothesis in this study indicate that $\mathrm{H} 5 \mathrm{a}$ and $\mathrm{H} 5 \mathrm{~B}$ positive effect but not statistically significant so H5a and H5B unsupported auditor independence means no effect on accounting conservatism. Results of the study is not significant because the sample only two companies during the study period were conservative with the difference in net income with operational cash flow is negative with an average statistical value of non-operating accrual show positive signs, which means the company is not 
applying conservative accounting so clear that the auditor has no effect on accounting conservatism.

\section{Conclusion}

Based on the above results on the effect of auditor independence and corporate governance to accounting conservatism companies listed on the Stock Exchange in 2010-2014, it can be concluded as follows:

1. Statistical tests showed that managerial ownership does not significantly influence good accounting conservatism measured by market value as well as non-operating accrual. Those results meant that a relatively small managerial ownership allows a conflict of interest between shareholders and managers where the interests of managers can not be aligned with shareholder interests so that managers are yet to have the company.

2. The leverage does not significantly influence good accounting conservatism as measured using market value as well as non-operating accrual. These results indicate that an increase or decrease in the ratio of total debt to assets owned by the company do not affect the application of conservative accounting. The company's assets financed by debt is so large that the company's managers will choose accounting procedures that increase in reported earnings is not conservative.

3. Statistical tests showed that profitability does not significantly influence good accounting conservatism as measured using market value as well as non-operating accrual. This result indicates that the net profit resulting from the use of the company's total assets had no significant effect on the market-to-book ratios and non-operating accrual reflects the application of the principle of accounting conservatism. Net income derived from the use of assets does not affect the management policy for applying conservative accounting because the average profit generated in 2010-2014 manufacturing companies tend to be low so that the management does not need to apply the principle of conservatives who make profits fluctuating or unstable.
4. The size of the company's significant negative effect on accounting conservatism as measured by market value. Small size of the companies that encourage managers to present the report tends to be conservative to avoid the high political cost. Size enterprises with non-operating accrual measurements show that the size of the company significant positive effect on accounting conservatism. The managers are trying to apply the principle of a more conservative so that profits appear to be low. It aims to avoid large political costs of external parties such as government.

5. Statistical tests showed that the independence of the auditor does not affect the application of accounting konsrvatisme whether measured by market value as well as non-operating accrual. Results are due in the study sample of only 18 companies in the study period is conservative, which means more companies are not applying conservative accounting so clear that the auditor has no effect on accounting conservatism.

\subsection{Limitation}

This study has several drawbacks, namely:

1. Uses only two sizes of conservatism that is the size of the market and the non-operating accrual.

2. The method of sample selection is purposive sampling so that researchers can select the exact results and the data obtained in accordance with the criteria to be tested but this method has the disadvantage of lack of generalizability of this study.

3. This study uses one type of industry, namely manufacturing companies listed in Indonesia Stock Exchange 2010-2014 period as many as 49 companies that have not been able to represent and explain the greater influence on performance appraisal companies.

\subsection{Implication and suggestions}

From the conclusions that have been obtained, it can be given some suggestions are:

1. For the same research should expand the study sample.

2. Future studies may use different measurement conservatism. 


\section{References}

[1] Ahmed, A. S., \& Duellman, S. (2007). Accounting Conservatism And Board Of Director Characteristics: An Empirical Analysis. Journal Of Accounting And Economics.

[2] Ali, M. C. (2015, October 9). Auditor Independence And Accounting Conservatism. International Journal of Accounting \& Information Management, 23(1), 80-104.

[3] Ayu Martaning Yogi Ardina, I. J. (2012). Penggunaan Perspektif Positive Accounting Theory Terhadap Konservatisme Akuntansi Di Indonesia. Diponegoro Journal Accounting, $1-15$.

[4] Bahaudin, Arif, A., \& Wijayanti, P. (2011). Mekanisme Corporate Governance Terhadap Konservatisme Akuntansi Di Indonesia. Dinamika Sosial Ekonomi, Volume 7 Nomor 1,Edisis Mei 2011,86-100.

[5] Basu, S. (1997). The Conservatism Principle And The Asymmetric Timeliness Of Earnings. Journal Of Accounting And Economics, 3-37.

[6] Basu, S., Hwang, L., \& Jan, C.-L. (2001). Differences In Conservatism Between Big Eight And Non-Big Eight Auditors. Working Paper.

[7] Bhuiyan, M. H., \& Biswas, P. K. (2007). Corporate Governance And Reporting: An Empirical Study Of The. Journal Of Business Studies, Vol. Xxviii.

[8] Deangelo, L. E. (1981). Auditor Size And Audit Quality. Journal Of Accounting And Economics, 3(3), 183-199.

[9] Calvin, O. (2012). Faktor-Faktor Yang Mempengaruhi Penerapan Konservatisme Pada Perusahaan Manufaktur Di Bei. Jurnal Ilmiah Mahasiswa Akuntansi

[10] Cynthia, S., \& Desi, A. (2009). Konservatisme Perusahaan di Indonesia dan Faktor-Faktor yang Mempengaruhinya.

[11] Dewi, N. K., \& Suryanawa, I. K. (2014). Pengaruh Struktur Kepemilikan Manajerial, Leverage, Dan Financial Distress Terhadap Konservatisme Akuntansi. E-Jurnal Akuntansi Universitas Udayana.

[12] Effendi, M. A. (2009). The Power Of Good Corporate Governance:Teori Dan Implementasi;Editor. Krista.

[13] Fasb. (1980). Qualitative Characteristics Of Accounting Information, Statement Of Financial Accounting Concept No.2.

[14] Givoly, D. H. (2000). The Changing Time-Series Properties Of Earnings, Cash Flows And Acrruals: Has Financial Reporting Becomes More Conservative ? Journal Of Accounting And Economics 29, 287-320.
[15] Kiel, G. C., \& Nicholson, G. J. (2002). Board Composition And Corporate Performance: How The Australian Experince Informs Contrasting Theories Of Corporate Governance.

[16] Lafond, R., \& Roychowdhury, S. (2007). Managerial Ownership And Accounting Conservatism.

[17] Lo, E. W. (2005). Pengaruh Tingkat Kesulitan Keuangan Perusahaan Terhadap Konservatisme Akuntansi. Simposium Nasional Akuntansi Viii.

[18] Natalia, F. (2014). Pengaruh Corporate Governance Pada Konservatisme Akuntansi Perusahaan Manufaktur Di Bursa Efek Indonesia. E-Jurnal Akuntansi Universitas Udayana, $509-523$.

[19] Padmawati, I. R., \& Fachrurrozie. (2015). Pengaruh Mekanisme Good Corporate Governance Dan Kualitas Audit Terhadap Tingkat Konservatisme Akuntansi. Accounting Analysis Journal.

[20] Peraturan Menteri Keuangan Tentang Jasa Akuntan Publik. (N.D.). Retrieved February 2016, From Http://Www.Google.Com

[21] Sari, D. (2004). Hubungan Antara Konservatisme Akuntansi Dengan Konflik Bondholders-Shareholders. Prosiding, Simposium Nasional.

[22] Shleifer, A., \& W.Vishny, R. (1997). A Survey Of Corporate Governance. The Journal Of Finance.

[23] Siska, F. (2012). Konservatisme Akuntansi, Corporate Governance, Dan Kualitas Laba ( Studi Empiris Pada Perusahaan Manufaktur Yang Terdaftar Di Bursa Efek Indonesia Periode (2008-2010)

[24] Wardhani, R. (2008). Tingkat Konservatisme Akuntansi Di Indonesia Dan Hubungannya Dengan Karakteristik Dewan Sebagai Salah Satu Mekanisme Corporate Governance. Universitas Indonesia. Simposium Nasional Akuntansi Xi.

[25] Watts, R. L. (2003). Conservatism In Accounting Part I: Explanations And Implications. Accounting Horizons 17, 207-221.

[26] Xingrong, Q. (2003). The Economic Determinants Of Self-Imposed Accounting Conservatism Dissertation. State University Of New York At Buffalo(January) , 1-41.

[27] Yona, E. E. (2013). Pengaruh Konservatisme Akuntansi Terhadap Penilaian Ekuitas Dengan Good Corporate Governance Sebagai Varaibel Pemoderasi (Studi Empiris Pada Perusahaan Manufaktur Yang Terdaftar Di PT BEI). 